\title{
A THEORETICAL FRAMEWORK FOR THE EVALUATION OF VIRTUAL REALITY TECHNOLOGIES PRIOR TO USE: A BIOLOGICAL EVOLUTIONARY APPROACH BASED ON A MODIFIED MEDIA NATURALNESS THEORY
}

\author{
Onur YUMURTACI \\ Anadolu University, Turkey \\ oyumurtaci@anadolu.edu.tr
}

\begin{abstract}
The rapid development of information and communication technologies has opened a whole new realm of applications for these technologies. One such application is the development of virtual reality, which aspires to immerse the user within the system such that they feel more "present" within the portrayed virtual plane of existence than within their true reality. Many studies have developed a variety of approaches and methods on measuring immersion and presence in these systems, yet few have addressed the underlying technology for what it really is - namely communication technology and evaluated the technology's potential for immersion and presence before exposing the user to the virtual experience. Part of the issue lies in the difficulty in quantifying arguably subjective experiences such as immersion and presence. This study examines the existing literature on the definition and evaluation of immersion, presence, and virtual reality technologies, and aims to provide a theoretical framework through which virtual reality technology may be evaluated based on the human biological apparatus it appeals to. The framework is constructed on a modified version of the Media Naturalness Theory, which was selected as a basis due to the evolutionary support it provides in explaining our communication preferences. The framework may then be utilized to analyze prospective technologies for their potential to provide immersive experiences and incite presence in the users before any exposure or use has taken place, possibly providing further validity to any findings of post-exposure studies (such as with questionnaires so ubiquitous in the literature of the field).
\end{abstract}

Keywords: virtual reality, technology, immersion, presence, Media Naturalness Theory.

\section{KULLANIM ÖNCESINDE SANAL GERÇEKLİK TEKNOLOJILLERININ DEĞERLENDİRILMESİ İÇİN BİR KURAMSAL ÇERÇEVE: UYARLANMIŞ İLETIŞIMM ORTAMLARI DOĞALLIĞI KURAMI TEMELINDE BİR BIYYOLOJIKK EVRIMMSEL YAKLAŞIM}

ÖZ

Bilişim teknolojilerinin hızlı gelişimi, bu teknolojilerin uygulamalarına ilişkin geniş bir dünyanın oluşmasına neden olmuştur. Bu kullanımlardan biri de, kullanıcısını sistemin içinde soyutlayarak onun gerçekten var olduğu gerçekliğe oranla sistem tarafından sunulan sanal alemde daha fazla bulunma hissini sunmaya çalışan sanal gerçeklik olmaktadır. Bu sistemlerdeki soyutlama ve bulunuşluğun ölçülebilmesi ile ilgili çeşitli yaklaşım ve yöntemlerin sunulduğu çalışmalar alanyazında (ve bu çalışma kapsamında gerçekleştirilen alanyazın taramasında) yer almaktadır; ancak mevcut çalışmalarda bu teknolojilerin temelini oluşturan iletişim teknolojileri bakımından incelenmeleri ve kullanıcıya sanal gerçeklik deneyimi sunmadan önce, kullanılan araçların içsel soyutlama ve bulunuş sağlama potansiyellerine ilişkin bir yaklaşıma rastlanmamıştır. Bu konuda yaşanan sorunlardan birinin, öznel olarak görülebilecek soyutlama ve bulunuş hissinin ölçülebilir bir halde nicelendirilebilmesindeki sıkıntılar olduğundan söz etmek olasıdır. Bu çalışma, soyutlama, bulunuşluk ve sanal gerçekliğin tanımları ve değerlendirilmeleri ile ilgili alanyazını tarayarak sanal gerçeklik teknolojilerinin, hitap ettiği biyolojik duyularımızı temel alan bir yaklaşımla değerlendirilebilecekleri bir kuramsal çerçeve sunmayı amaçlamaktadır. Bu çerçeve, iletişim tercihlerimizi açıklarken evrimsel biyolojiye dayanması nedeniyle tercih edilen İletişim Ortamları 
Doğallığı Kuramı'nın uyarlanması ile oluşturulmuştur. Önerilen çerçeve, sanal gerçeklik için kullanılabilecek teknolojilerin kullanımlarından önce uygulanması yoluyla sunabilecekleri olas1 soyutlama ve bulunuşluk deneyimlerinin belirlenebilmesine yardımcı olarak (alanda yaygın olarak kullanılan anketler gibi) kullanım sonrasında gerçekleştirilen çalışmaların geçerliliklerine katkıda bulunabilecek olması dolayısıyla önem taşımaktadır.

Anahtar kelimeler: sanal gerçeklik, teknoloji, soyutlama, bulunuşluk, İletişim Ortamları Doğallığı Kurami.

\section{INTRODUCTION}

Considerable efforts are currently placed on the development of virtual and augmented reality in a plethora of current and prospective applications. Once relegated to the realm of science fiction, the rapid development of various technologies ranging from visualization and audio to communications and computing have allowed the realization of technology capable of fooling human perception into the process of virtualization. Even throughout the development of virtual reality technologies, the technical and practical aspects of systems hindered any pragmatic application of these systems, and yet these technologies have currently advanced, miniaturized, and matured to the extent that virtual reality systems have entered the consumer realm. This, in turn, has unleashed the underlying potential in such systems, as public access has historically been a significant contributor to the further development of technological advancements.

Within the scope of this study, a theoretical framework is proposed for the evaluation of virtual reality systems. This proposal is based on the fundamental understanding that beyond the technical capabilities and shortcomings innate to the ever-changing scope of technologies available to provide such services, virtual reality systems are in essence mediums of communication. They appeal to the senses to a degree that surpasses "traditional" mediums and modes of communication such as television, home theaters, gaming consoles, and even cinemas/film theaters. The level of involvement afforded to the senses through virtual reality systems establishes the basis of this study, in which the concepts of perception, immersion, and presence are discussed through a literature review to establish the baseline of that which is expected of an effective virtual reality system. The findings of this literature review establish the need for new approaches and methods in the measurement and evaluation of virtual reality systems. This in turn is followed by a proposed framework to effectively measure virtual reality systems, and is based on the relatively recent Media Naturalness Theory. As will be discussed further below in the literature review, the aim of this proposal is not just to merely contribute to the vast literature already established in the field, but to approach the issue from a perspective congruent to the biological basis of perception and how we perceive as human beings. It is due to this aim that the proposed framework establishes a method of measurement involving the evaluation of the technologies utilized in virtual reality systems based on our human senses, and the level of immersion that technologies can provide to satisfy and stimulate those senses.

\section{PERCEPTION AS A COGNITIVE PROCESS}

Human biology has provided us with various apparatus with which to experience the world in which we live in. Commonly referred to as the "senses", human sensory perception is generally accepted to consist of sight, sound, touch, taste, and smell. Each sense responds in different ways and to different degrees to differing physical and chemical stimuli, resulting in the biological, physiological, and psychological process that allows us to survive in and experience the world in which we live in. The succession from stimuli, sense, perception, and eventual cognition are thus distinct concepts with specific defining characteristics. From this distinction, we must understand that the act of seeing is not the same as visual perception, wherein the former is the biological process of receiving visual stimuli while the latter is the incorporation of this stimuli into our cognitive process. Perception itself is an act that requires attention and awareness, and is therefore a step in the transformation of our senses into consciousness (Stufflebeam, 2007: 2). By definition, cognition refers to the act of knowing, in which we interpret our cognitive process such that we have a complete understanding of that which we perceive. Thus, our brain attempts to understand or create meaning from the stimuli that we are 
exposed to, and is capable of doing this through the sensory data gathered from our senses. In most cases, this initial stage of perception is random in that it stems from random stimuli that we happen to be exposed to and may therefore be called exposure. In instances that are not random, wherein we actively choose stimuli through attention, this process of understanding stimuli is called interpretation (Perner, 2010: 1-3). Through this process of interpretation, we determine our relationship with and attitude towards that which we are perceiving. Attitude, in turn, emerges from both the relationship between our beliefs, feelings, and behavioral intent, and from their cumulative products (Perner, 2010: 1-2).

From this understanding of how perception works as a cognitive process, beginning with our senses and resulting in our conscious cognitive decisions and attitudes, the final result of the process as a whole would be behavior. The underlying differences between each individual, however, result in the fact that two people may portray different attitudes and behaviors even when they are looking at the same thing; due to their differences in perception (Fishbein \& Ajzen, 1975: 50-51). While attitudes and behaviors may differ, studies have indicated that measuring perceptions by measuring the process from perception to conscious behavior is indeed possible (Ajzen \& Fishbein, 1977: 888-918). Stemming from this ability to measure human behavior through their perceptions, theories such as the Theory of Reasoned Action and the Theory of Planned Behavior have been utilized to great effect.

Considering how the way we experience our surroundings through our senses is a deeply personal process involving physical, physiological, psychological, and experiential elements participating in harmony to establish our perceptions and thereby behaviors, this process as a whole may be integrated into the sensory trickery that is virtual reality (VR). Just as it has been posited that our perceptions may be measured, various measures exist in relation to how we perceive, react, and behave in virtual environments. These measures are discussed further in the following sections.

\section{PRESENCE: A CONFLICT OF INTERESTS}

Unfortunately for research in the field, there is no single definition of presence utilized in literature. While most accounts of the concept are at least similar, they do on occasion differ significantly enough to cause differing meanings. The differentiation in terminology and reference has reached the point where the study of the concept of presence has become a field unto itself. That being said, a brief overview of this field is prudent in better understanding the intent of this study as well.

Witmer and Singer (1998), for example, define presence as "the subjective experience of being in one place or environment, even when one is physically situated in another". The authors continue, indicating that presence in virtual environments may be achieved to varying degrees based on the satisfaction of variables such as the necessary conditions for presence (namely the allocation of selective attention), the psychological state of involvement (a consequence of focusing one's energy and attention on a coherent set of stimuli or related activities and events), the psychological state of immersion (perceiving oneself to be enveloped by, included in, and interacting with an environment that provides a continuous stream of stimuli and experiences), and the eventual establishment of presence. They posit that in essence, both involvement and immersion are necessary for experiencing presence, thus a valid measure of presence should address factors that influence involvement as well as those that affect immersion (Witmer \& Singer, 1998: 227-228). The authors continue, indicating that the following factors are also influential in measuring presence (1998: 228-230):

1. Control Factors.

a. Degree of control.

b. Immediacy of control.

c. Anticipation.

d. Mode of control.

e. Physical environmental modifiability.

2. Sensory Factors.

a. Sensory modality. 
b. Environmental richness.

c. Multimodal presentation.

d. Consistency of multimodal information.

e. Degree of movement perception.

f. Active search

3. Distraction Factors.

a. Isolation.

b. Selective attention.

c. Interface awareness.

4. Realism Factors.
a. Scene realism.
b. Consistency of information with the objective world.
c. Meaningfulness of experience.
d. Separation anxiety/disorientation.

Witner and Singer then derive primarily from these base and contributing factors, a framework for developing questionnaires with the goal of measuring presence in virtual environments.

In direct response to Witner and Singer, Mel Slater (1999) notes that while Witner and Singer "did not agree with my notion of immersion" as their study states that immersion itself is not an objective description of virtual environment technology. This disagreement seemingly stems from the fact that Slater defines immersion to refer to "the extent to which the actual system delivers a surrounding environment, one which shuts out sensations from the 'real world', which accommodates many sensory modalities, has rich representational capability, and so on..." (Slater, 1999: 560). Slater then continues to identify the fact that Witner and Singer specifically refer to immersion as the person's response to virtual environment systems, thereby requiring the distinction between 'system immersion' and 'immersive response'. In this regard, Slater indicates that in their own research, presence itself includes the following aspects (1999: 561):

- The sense of 'being there' in the environment depicted by the virtual environment (VE).

- The extent to which the VE becomes the dominant one - i.e., that participants will respond to events in the VE rather than in the 'real world'.

- The extent to which participants, after the VE experience, remember it as having visited a 'place' rather than just having seen images generated by a computer.

Slater finally posits that the framework for presence measurement is flawed in and of itself, as many of the proposed questions in reference to the various factors influencing presence listed above are innately objective. This, in turn, elicits the opinions of participants, while expecting an objective measure of presence through factors that are not necessarily independent of each other.

A brief foray into Slater's earlier work indicates a more direct reference to the distinction between immersion and presence, and the causality derived from increased immersion (Slater \& Wilbur, 1997). In this study, immersion is defined as follows (1997: 606):

"Immersion is a description of a technology, and describes the extent to which the computer displays are capable of delivering an inclusive, extensive, surrounding and vivid illusion of reality to the senses of a human participant. Inclusive (I) indicates the extent to which physical reality is shut out. Extensive (E) indicates the range of sensory modalities accommodated. Surrounding $(S)$ indicates the extent to which this virtual reality is panoramic rather than limited to a narrow field. Vivid (V) indicates the resolution, fidelity, and variety of energy simulated within a particular modality (for example, the visual and colour resolution). Vividness is concerned with the richness, information content, resolution and quality of the displays." 
Presence, on the other hand, is defined thusly in the same study:

"Immersion can be an objective and quantifiable description of what any particular system does provide. Presence is a state of consciousness, the (psychological) sense of being in the virtual environment. Presence has been studied by many researchers in recent years, for example (Heeter, 1992; Held and Durlach, 1992; Loomis, 1992; Sheridan, 1992; Steur, 1992; Barfield and Weghorst, 1993; Barfield et. al., 1995). The fundamental idea is that participants who are highly present should experience the VE as more the engaging reality than the surrounding physical world, and consider the environment specified by the displays as places visited rather than as images seen."

Later studies that have analyzed the distinction between presence and immersion have also drawn from Slater's definitions and differentiations, while still accepting that both concepts are complex and at times confusing constructs (Constantin \& Grigorovici, 2003). While the cumulative evidence is not compelling enough to determine one way or another, and even though there appears to be an academic consensus that immersion influences presence, studies do not converge on immersion as the primarily quantifiable measure, and diversify in the measuring of both immersion and presence.

Further studies also draw attention to the issues surrounding defining concepts in the field. Insko (2003) provides the following statement regarding the definition of presence:

"The definition of presence has yet to be agreed upon by researchers. There are two definitions of presence that are most often discussed in the literature. The first is the "sense of being there" in one place or environment (i.e. a virtual environment) even when one is physically situated in another [1]. The second is the "perceptual illusion of nonmediation" [2]. This says that a participant experiences presence, when he fails to perceive or acknowledge that the environment is being presented to him through some type of media (e.g. television, HMDs).

The lack of a single accepted definition, and the subjective nature of the above definitions, leads to difficulty in quantifying a participant's presence. The first presence measures investigated were post-immersion questionnaires. These asked the user directly questions about presence or factors related to presence. In an effort to create more objective measures, behavioral and physiological methods were introduced."

As may be inferred from the literature thus far analyzed, the issue of achieving a clear definition regarding concepts such as immersion and presence is an ongoing one. Some research differentiates between real world presence and presence mediated through technology (Coelho, Tichon, Hine, Wallis, \& Riva, 2006). Other studies have conducted literature reviews that reveal the shortcomings of attempting to measure presence through the various definitions and factors involving it (Shuemie, Van Der Straaten, Krijn, \& Van Der Mast, 2001). Some researchers have accepted the terminological conundrum and focused on issues such as methodological variables and different approaches to measuring presence (Insko, 2003). In 2004, an exhaustive report funded by the European Community under the Information Society Technologies Program was published, collecting and analyzing possibly all of the established methods and approaches towards the measurement of presence in academic literature (van Baren \& IJsselsteijn, 2004). The comprehensive report is indicative of how varied research in the field of presence may be, and underlines a key issue in research in the field: for the most part, measuring presence is a post facto process in which "participants" of an experiential event provide insight into their experiences. This, in turn, reveals that for the most part, the effective measurement of virtual reality technologies is conducted only after the design, production, and execution (or application) of a VR system has been completed. This deficiency in measurement brings us to one of the defining factors in measuring VR technologies and their efficacies: immersion.

\section{IMMERSION: CHECKING THE DEPTH OF THE POOL WITHOUT GETTING WET}

As discussed above, the issues surrounding the measurement of presence are varied, and the relationship between immersion and presence is also a strenuous one. Despite the discrepancies between the definitions of and relationships between presence and immersion (Witmer \& Singer, 1998; Slater, 1999; Constantin \& Grigorovici, 2003; Shuemie, Van Der Straaten, Krijn, \& Van Der 
Mast, 2001), research in the field of presence commonly accepts a correlative relationship between immersion and presence while disregarding immersion as the primarily quantifiable measure, instead turning to methods and approaches in an attempt to measure presence. This trend to supersede immersion in presence research has resulted in the fields of presence and immersion studies diverging, and immersion research establishing a whole field of their own. Drawing from the aforementioned issue rising from measuring presence as a post facto process, this study draws from literature indicating that immersion is indicative of presence and therefore places emphasis on the measurement of immersion in accordance with the aims of this study. This approach is supported by literature in the field of immersion studies (Schubert, Friedmann, \& Regenbrecht, 2001) (Krijn, Emmelkamp, Biemond, de Ligny, Schuemie, \& van der Mast, 2004) (Slater, Lotto, Arnold, \& Sanchez-Vives, 2009) (McMahan, 2003) which identify immersion as the objective qualification of VR equipment that influences presence.

Similar to the issues discussed in measuring presence, measuring immersion also has no universal scale. For example, one study utilizes the number of sensorial channels, pictorial realism, system response time, control, and field of vision to refer to the immersion provided by VR systems, while elements such as body representation the presence of others are categorized under media characteristics independent of the actual technology being used (Coelho, Tichon, Hine, Wallis, \& Riva, 2006). Insko (2003) draws attention to the advantages and disadvantages of subjective, behavioral, and physiological measures for measuring presence while also noting that other than physiological measure which may be conducted in real-time measurement or as a pre and post test for comparative results, all of the measures mentioned are post-immersion; they only postulate to be able to measure anything after whatever it is that is being measured has taken place and been completed. Some studies draw attention to the issues surrounding the definitions of immersion and presence, and postulate that a mixed approach of subjective and objective measures in determining immersion is ideal (Cairns, Berthouze, Dopharee, \& Jennet, 2006). Burns \& Fairclough (2015) conducted their study by placing focus on sensory immersion and challenge immersion, drawing attention to immersion being measured through feedback from sensory stimuli. The studies in the field are vast, ranging from measuring immersion through abstract concepts such as avatars (Farrow \& Iacovides, 2014), to immersion as a result of social engagement (Grinberg, Careaga, Mehl, \& O'Connor, 2014), while others have studied for form and content to determine the relationship between immersion, emotion, and presence (Banos, Botella, Alcaniz, Liano, Guerrero, \& Rey, 2004). One study, however, draws attention to how studies in the field focus on how immersion, presence, and VR systems are measured through outcomes and provides some insight as to the inputs that must go into designing VR systems for immersion and presence in the first place - thereby drawing focus to the usability of systems (Sun, Li, Zhu, \& Hsiao, 2015). This, in turn draws attention to the more tangible aspects of VR. Setting aside for a moment the issues regarding definitions and terminology surrounding immersion, an objective measure for the evaluation of immersion in VR systems must deal in more tangible and explicit aspects of such systems. The influence that the actual technology used in the level of immersion that may be achieved is well documented through studies that measure the effects of screen size on immersion and the ensuing user attitudes and intents to use (Hou, Nam, Peng, \& Lee, 2012), (Biocca, Daugherty, Chae, \& Li, 2001) and similar studies on the technical aspects of systems such as depth perception in three dimensional viewing experiences and their influence on immersion (Ijsselsteijn, Ridder, Bouwhuis, \& Freeman, 1997). While previous studies exist that propose objective measures for the measurement of immersion, they are based on the measurement of variables such as screen size, resolution, control methods, and latency (Cairns, Berthouze, Dopharee, \& Jennet, 2006), or cognitive factors such as imagination, suspension of disbelief, interactivity, sensory completeness, fatigue, disorientation (Psotka \& Davison, 1993) - all of which are valid constructs with which immersion has been measured, they are elements of VR system design developed and tailored to post facto immersion and presence studies without the theoretical basis of a theory as to why such elements are effective in immersion. Based on this shortcoming, this study proposes the Media Naturalness Theory as a theoretical approach to better understanding the requirements of VR systems and establishing a human oriented basis from which measurement and evaluation may take place. 


\section{MEDIA NATURALNESS THEORY}

Taking into account the literature reviewed above, along with the goal to provide a theoretical basis through which immersion in virtual reality may be postulated before actually the system to users, the Media Naturalness Theory (MNT) appears to be a suitable approach. Based on the assumption of the theory of evolution, MNT asserts that the result of human evolution is that our senses have evolved in a manner best suited for face to face communication (Kock, 2001). This approach stems from previous studies in communication that failed to satisfactorily explain the human preference and need for face to face communication (Kock, 2005: 117; Kock, 2001: 1-7; Kinney \& Dennis, 1994). MNT itself is based on the Media Richness Theory, which posits that face to face communication is the "richest" medium of communication, but fails to base this preference on a sound theoretical basis. MNT, which overcomes the shortcomings of the Media Richness Theory, is based on the biological means we have to perceive the world around us, and bases it's determination of media choice on our human physiology.

Kock (2005: 117-132) indicates that while the human body has evolved over an immense amount of time to perfect face to face communication, it has not had time to evolve to better utilize new communication technologies. This is why we must develop these technologies to better fit our human capabilities in the first place, and this in turn is determined by how "natural" these technologies are. A reduction in the naturalness of communication media causes increased perceptive and cognitive effort, increased communication ambiguity, and reduced physiological arousal. In this regard, the "naturalness" of a communication medium is determinant of the success of communication, and thereby the tools utilized for said communication. Kock (2004) indicates that the vast potential of communication technologies are greatly limited by the limitations of human evolution, thus limiting the development of communication technologies to our own limitations of senses and sensory perception.

The three main dependent constructs of the media naturalness hypothesis are identified as cognitive effort, communication ambiguity, and physiological arousal (Kock, 2005: 124). It is also posited that natural communication involves five key attributes (Kock, 2005: 121):

- A high degree of co-location, which would allow the individuals engaged in a communication interaction to see and hear each other, as well as share the same environment while engaging in communication,

- A high degree of synchronicity, which would allow the individuals engaged in a communication interaction to quickly exchange communicative stimuli,

- The ability to convey and observe facial expressions,

- The ability to convey and observe body language,

- And the ability to convey and listen to speech.

Kock then postulates that the naturalness of a communication medium created by a communication technology may be determined by the degree to which the technology incorporates (or suppresses) these five elements.

\section{MEDIA NATURALNESS IN AN UNNATURAL WORLD}

This study proposes the use of the Media Naturalness Theory for the evaluation of the technology used for virtual reality systems. Taking into account, for a moment, the fact that MNT is based on the evolution of our biological apparatus which has evolved for the optimization of face to face communication, MNT must be somewhat modified in accordance with the goal of this study. To be able to keep the sound theoretical basis of evolutionary sensory apparatus being tailored to face to face communication, yet utilize this approach in a fully synthetic environment to establish predetermined expectations of the technology being utilized, we must re-visit the five key attributes of media naturalness to determine what may be used as proxy in the absence of a second "face" in face to face communication.

Co-location: The term "co-location" itself may appear to imply a sense of presence in and of itself. Within the context of MNT, it may even be seen as a term synonymous with telepresence. Due to the fact that in many cases, VR is not necessarily a social medium and yet still relevantly alters the perceived location of the user, in the context of using MNT to assess the technological capabilities, 
this attribute may be modified to refer to the degree to which the user is removed from reality. In the case of assessing technology and it's capability of immersing it's user, co-location may refer to relocation, as in the degree to which the user is removed from the physical reality they exist in, and placed in the reality presented to them within the system. As such, re-location would refer to how many senses of the user a system isolates, along with the degree to which these senses are stimulated in a manner plausible to the user in that their suspension of disbelief is satisfied.

Synchronicity: Previous studies in immersion have studied issues such as latency, lag, and the general speed of the systems utilized. Synchronicity would implicitly refer to such variables, as any delay in the presentation of virtuality would in essence alert the user to the faux nature of what they are perceiving, thereby dismantling the suspension of disbelief.

The ability to convey and observe facial expressions and body language: These attributes of MNT would refer to the visual and optical aspects of VR, in that without it such portrayals would not be possible. That being said, considering VR is not an exclusively social endeavor, any referral to the visual aspect of VR should not be limited to the expression of facial or physical cues. As such, taking into account how the observation of facial expressions would require the capability of visualizing minute changes, and the observation of body language would require the capability of seeing large objects, these two criteria may be attributed to resolution and field of view. Any technology attempting to portray diminutive changes such as facial expressions must be able to both capture and display those changes in enough detail that the user is capable of portraying and observing them. Similarly, the ability to convey and observe body language requires that the system is capable of capturing and displaying the whole body of users, and would thus require a wide field of view. Properties enhancing the visual aspect of a system such as stereoscopy, color gamut, and other display properties would be categorized under these attributes.

The ability to convey and listen to speech: As indicated in reference to co-location, the term speech may be taken beyond the social context of face to face communication regarding VR technology. The ability to convey and listen to audio would satisfy the need for aural perception in VR systems, and the degree to which this satisfaction is provided may be attributed to qualities such as fidelity, volume, and directionality. To provide an immersive VR experience, the technology being used would be expected to take advantage of our binaural physiology. These aspects may be categorized under the simple audio attribute.

Given the above appropriations for adapting MNT to better evaluate VR technology, certain shortcomings of this approach may also become apparent. The foremost of which is the distinct lack of addressing other sensory perceptions, namely touch, taste, and smell. While tactile feedback may not be a widely considered aspect of modern face to face communication (especially considering the modern western social norm of "personal space"), touch is a key sense with which we perceive and understand our environment. The sensory cues attributed to this sense range from temperature to texture, and tangentially, from pain to pleasure. Disregarding this amount of sensory input would, at first, seem short sighted and negligent. The fact of the matter is that while our sense of touch is capable of conveying a plethora of information, as of this study, we simply do not have the technology capable of portraying such a broad range of feedback with the necessary tactile detail for a convincing VR experience. The same situation holds true for the sense of smell and taste. Despite the existence of previous applications of smell in immersive experiences such as film and other viewing experiences (Smell-O-Vision, AromaRama etc.) dating back to the early 1900s, the unfortunate fact of the matter is that the real-world limitations of physics and chemistry prevent the production of a system capable of replicating the vast range of smell and taste we are able to perceive, with even modern systems (FeelReal) only capable of offering a limited range of aromas in consumable cartridges.

Taking into account the technical limitations involved in appealing to the senses of touch, taste, and smell, an additional category of evaluation to refer to any additional sensory appeal, supplementary feedback, is proposed to refer to the degree to which additional inputs contribute to the replication of face to face communication in a convincing manner. Additional user inputs such as body, face, and 
head tracking along with control methods would also fall into this category. By adapting the elements of MNT to better suit the evaluation of VR technology as communication technologies, certain aspects of technology may be evaluated in comparison to face to face communication before the implementation of these technologies, greatly reducing the ambiguity and variation expected of postuse research.

\section{PROOF-OF-CONCEPT EXAMPLES}

To better illustrate how the modified MNT elements would be applied to communication technologies, the following examples use the attributes listed above in context with currently available communication technologies. This study proposes that a similar application of this approach to VR systems would be effective in the pre-determination of the level of immersion through a comparison of these attributes with face to face communication. These examples, provided based on traditional media such as film and television, may be expanded upon to encompass new communication technologies aspiring to provide virtual experiences. The traits of each system analyzed based on their naturalness attributes would be indicative of their capability to ensure the required immersion and eventual sense of presence.

\begin{tabular}{|c|c|c|}
\hline & \multicolumn{2}{|r|}{ Television } \\
\hline \multirow{6}{*}{$\begin{array}{l}\text { Media } \\
\text { Naturalness }\end{array}$} & Re-location & The user is not isolated from external sensory input \\
\hline & Synchronicity & $\begin{array}{l}\text { Traditionally considered a passive audience experience, } \\
\text { television does not inherently possess the interactive } \\
\text { features required to measure synchronicity. }\end{array}$ \\
\hline & Resolution & $\begin{array}{l}\text { Modern televisions are capable of achieving resolutions } \\
\text { high enough to convey immense detail, but the distance } \\
\text { between the viewing surface and user cause high } \\
\text { variation in the ability of the user to detect detail. }\end{array}$ \\
\hline & $\begin{array}{l}\text { Field of View } \\
(\text { FoV) }\end{array}$ & $\begin{array}{l}\text { The combined measures of screen size and distance to } \\
\text { screen cause great variation in the FoV, and } \\
\text { traditionally the FoV for viewing is low. The lack of an } \\
\text { implicit interactivity somewhat negates the } \\
\text { measurement of expressed FoV. }\end{array}$ \\
\hline & Audio & $\begin{array}{l}\text { Most televisions possess stereo speakers capable of } \\
\text { somewhat satisfying the binaural apparatus we possess. } \\
\text { The simulation of immersive surround sound may be } \\
\text { provided by directional speakers or the addition of } \\
\text { more speakers. }\end{array}$ \\
\hline & $\begin{array}{l}\text { Supplementary } \\
\text { Feedback }\end{array}$ & No supplementary feedback is provided. \\
\hline
\end{tabular}

Figure 1: Media Naturalness of Television.

\begin{tabular}{|l|l|l|}
\cline { 2 - 3 } & \multicolumn{2}{c|}{ Cinema/Movie Theater } \\
\hline Media Naturalness & Re-location & $\begin{array}{l}\text { The user is somewhat isolated from external sensory } \\
\text { input, but as a commonly shared experience, the sense } \\
\text { of re-location is limited. }\end{array}$ \\
\hline
\end{tabular}




\begin{tabular}{|l|l|l|}
\hline Synchronicity & $\begin{array}{l}\text { Traditionally considered a passive audience experience, } \\
\text { film does not inherently possess the interactive features } \\
\text { required to measure synchronicity. }\end{array}$ \\
\hline Resolution & $\begin{array}{l}\text { Both analog and digital films possess very high } \\
\text { resolutions capable of conveying immense detail. So } \\
\text { much so, that the portrayal of details imperceptible to } \\
\text { human vision surpasses the level of face to face } \\
\text { communication, thereby introducing a somewhat } \\
\text { unnatural degree of detail. }\end{array}$ \\
\hline $\begin{array}{ll}\text { Field of View } \\
\text { (FoV) }\end{array}$ & $\begin{array}{l}\text { The immense screen size of movie theaters contributes } \\
\text { greatly in occupying the FoV of the audience, } \\
\text { contributing to the sense of re-location. The FoV is, } \\
\text { however, dependent on screen size and the distance } \\
\text { between the user and the screen. }\end{array}$ \\
\hline Audio & $\begin{array}{l}\text { Movie theaters commonly house a plethora of audio } \\
\text { sources capable of reproducing the full range of human } \\
\text { hearing from every direction. They may truly surround } \\
\text { the user in sound, appealing convincingly to the user's } \\
\text { binaural hearing. }\end{array}$ \\
\hline $\begin{array}{l}\text { Supplementary } \\
\text { Feedback }\end{array}$ & \begin{tabular}{l} 
No supplementary feedback is provided. \\
\hline
\end{tabular} \\
\hline
\end{tabular}

Figure 2: Media Naturalness of Cinema.

While the above examples are provided based on well established existing communication mediums, newer technologies such as "multi dimensional cinemas" which claim to provide a more immersive movie going experience, for example, could also be analyzed through the lens of MNT. The movement of the seating, and the spraying of water vapor in these theaters would exemplify instances of supplementary feedback.

\section{CONCLUSION}

Within the scope of this study, a literature review of the field revealed the need for a theoretical framework to evaluate communication technologies used in virtual environments as a pre-test rather than post-test. The proposed theoretical framework is based on the Media Naturalness Theory, and has been adapted to better suit the circumstances of evaluating new communication technologies in VR applications but still being grounded in the concept of the evolutionary capabilities of our senses. By providing this framework, it is hoped that future developments, studies, and applications in VR technology may keep sight of the fact that the end user, after all, is human. While many of the concepts proposed within this study may seem implicit - such as the fact that higher resolution displays occupying a greater field of view of the user would immerse the user to a higher degree and contribute to the sense of presence - such statements are presented in the literature as results of posttests, mainly as results of user responses to questionnaires quantifying their experiences with a system. The theoretical framework proposed in this study explicitly bases these assumptions on our human biology, thereby providing a stronger foundation on which to base any such research relying on user experiences. By providing this theoretical framework as something to be utilized a priori, this study hopes to precede the issues surrounding the definitions and measurements of immersion and presence. This being the case, the framework proposed in this study is an ad hoc approach to the evaluation of communication technology in VR, and whether or not it may prove itself useful beyond this scope is a matter for other studies. Similarly, the argument may be made that previous post-test 
studies, along with research that may be conducted in the future, have already addressed the values of measurement proposed in this research. This argument, however, fails to address the issue of having a set of guidelines (based on human physiology in this case) on which researchers may rely on to substantiate these values of measurement.

Lastly, as some studies have proposed that presence itself is so subjective, it is in and of itself either a personal or social construct (Mantovani \& Riva, 1999), or suggested that the experience of presence itself is dependent on the individual being willing to alter their consciousness to a degree that the suspension of disbelief reaches a level that reaches a form of cognition that is considered "makebelieve" - insinuating that it's all in our head, regardless of external influence, or measures, quantifiable or otherwise (Turner, 2015; Turner, Turner \& Carruthers, 2014). While the will to classify these concepts as immeasurable and intangible constructs (be they social, cognitive, subjective or otherwise abstract) may be tempting, disregarding the evidence in favor of immersion and presence being somewhat grounded in the concrete reality in which we exist in the first place would be counterproductive. While it is entirely possible and plausible that these concepts exist as a result of our ability to pretend, the physiological results of pretending are no less real. Under such circumstances, the value of starting out with that which is real in future studies - as proposed in this research - may prove valuable in better understanding the notional, transcendental nature of immersion and presence in future research, regardless of whether they result in quantifiable measures or not.

\section{REFERENCES}

Ajzen, I. (1991). The Theory of Planned Behavior. Organizational Behavior and Human Decision Processes , 50, 179-211.

Ajzen, I., \& Fishbein, M. (1977). Attitude-behavior relations: A theoretical analysis and review of empirical research. Psychological Bulletin , 84 (5), 888-918.

Ajzen, I., \& Fishbein, M. (1980). Understanding attitudes and predicting social behavior. New Jersey: Prentice-Hall.

Banos, R. M., Botella, C., Alcaniz, M., Liano, V., Guerrero, B., \& Rey, B. (2004). Immersion and Emotion: Their Impact on the Sense of Presence. Cyberpsychology \& Behavior , 7 (6), $734-$ 741.

Biocca, F., Daugherty, T., Chae, Z.-H., \& Li, H. (2001). Effect of visual sensory immersion on presence, product knowledge, attitude toward the product and purchase intention. Proceedings of the Experiential E-Commerce Conference. Est Lansing: Michigan State University.

Burns, C. G., \& Fairclough, S. H. (2015). Use of auditory event-related potentials to measure immersion during a computer game. International Journal of Human-Computer Studies , 73, 107-114.

Cairns, P. C., Berthouze, N., Dopharee, S., \& Jennet, C. (2006). Quantifying the experience of immersion in games. Cognitive Science of Games and Gameplay. Vancouver: CogSci.

Coelho, C., Tichon, J., Hine, T. J., Wallis, G., \& Riva, G. (2006). Media Presence and Inner Presence: The Sense of Presence in Virtual Reality Technologies. In G. Riva, M. T. Anguera, B. K. Wiederhold, \& F. Mantovani (Eds.), Communication to Presence: Cognition, Emotions and Culture Towards the Ultimate Communicative Experience (pp. 25-45). Amsterdam, Netherlands: IOS Press.

Constantin, C., \& Grigorovici, D. (2003). Virtual Environments and the Sense of Being There: An SEM Model of Presence . 6th Annual International Workshop on Presence (pp. 1-18). Aalborg, Denmark: The International Society for Presence Research (ISPR).

Farrow, R., \& Iacovides, I. (2014). Gaming and the limits of digital embodiment. Philosophy \& Technology , 27, 221-233.

FeelReal. (2015, February). Retrieved January 19, 2016, from FeelReal Web Site: http://www.feelreal.com

Grinberg, A. M., Careaga, J. S., Mehl, M. R., \& O'Connor, M.-F. (2014). Social engagement and user immersion in a socially based virtual world. Computers in Human Behavior, 36, 479-486.

Hou, J., Nam, Y., Peng, W., \& Lee, K. M. (2012). Effects of screen size, viewing angle, and players' immersion tendencies on game experience. Computers in Human Behavior , 28, 617-623. 
Ijsselsteijn, W. A., Ridder, H. d., Bouwhuis, D. G., \& Freeman, J. (1997). Perceived depth and the feeling of presence in 3DTV. Displays, 18, 207-214.

Insko, B. E. (2003). Measuring Presence: Subjective, Behavioral and Physiological Methods . In G. Riva, F. Davide, \& W. A. IJsselsteijn (Eds.), Being There: Concepts, Effects and Measurements of User Presence in Synthetic Environments (pp. 110-119). Amsterdam, Netherlands: IOS Press.

Kinney, S. T., \& Dennis, A. R. (1994). Re-evaluating media richness: Cues, feedback, and task. Hawaii International Conference on Systems Sciences (pp. 21-30). Hawaii: System Sciences.

Kock, N. (2005). Media Richness or Media Naturalness? The Evolution of Our Biological Communication Apparatus and Its Influence on Our Behavior Toward E-Communication Tools. IEEE Transactions on Professional Comunication , 48 (2), 117-132.

Kock, N. (2001). The Ape That Used EMail: Understanding E-Communication Behavior Through Evolution Theory. Communications of the Association for Information Systems , 5 (3), 1-29.

Kock, N. (2004). The Psychobiological Model: Towards a New Theory of Computer-Mediated Communication Based on Darwinian Evolution. Organization Science, 15 (3), 327-348.

Krijn, M., Emmelkamp, P. M., Biemond, R., de Ligny, C. d., Schuemie, M. J., \& van der Mast, C. A. (2004). Treatment of acrophobia in virtual reality: The role of immersion and presence. Nehaviour Research and Therapy , 42, 229-239.

Mantovani, G., \& Riva, G. (1999). "Real" Presence: How Different Ontologies Generate Different Criteria for Presence, Telepresence, and Virtual Presence. Presence: Teleoperators and Virtual Environments , 8 (5), 540-550.

McMahan, A. (2003). Immersion, Engagement, and Presence: A Mtheod for Analyzing 3-D Video Games. In M. J. Wolf, \& B. Perron (Eds.), The Video Game Theory Reader (pp. 67-86). New York: Routledge, Taylor \& Francis.

Perner, L. (2010). University of Southern California. Retrieved 12 18, 2010, from Consumer Behavior - Attitude: http://www.consumerpsychologist.com/cb_Attitudes.html

Perner, L. (2010). University of Southern California. Retrieved 12 18, 2010, from Consumer Behavior - Perception: http://www.consumerpsychologist.com/cb_Perception.html

Psotka, J., \& Davison, S. (1993). Cognitive Factors Associated with Immersion in Virtual Environments. Proceedings of the 1993 Conference on Intelligent Computer-Aided Training and Virtual Environment Technology (pp. 285-297). Houston: NASA.

Schubert, T. W., Friedmann, F., \& Regenbrecht, H. T. (2001). The Experience of Presence: Factor Analytic Insights. Presence: Teleoperators \& Virtual Environments, 10, 266-281.

Shuemie, M. J., Van Der Straaten, P., Krijn, M., \& Van Der Mast, J. A. (2001). Research on Presence in Virtual Reality: A Survey. Cyberpsychology \& Behavior , 4 (2), 183-201.

Slater, M. (1999). Measuring Presence: A Response to the Witmer and Singer Presence Questionnaire. Presence: Teleoperators and Virtual Environments , 8 (5), 560-565.

Slater, M., \& Wilbur, S. (1997). A framework for immersive virtual environments (FIVE): Speculations on the role of presence in virtual environments. Presence: Teleoperators and Virtual Environments , 6 (6), 603-616.

Slater, M., Lotto, B., Arnold, M. M., \& Sanchez-Vives, M. V. (2009). How we experience immersive virtual environments: the concept of presence and its measurement. Anuario de Psicologia, 40 (2), 193-210.

Stufflebeam, R. (2007). Perception: An Introduction. Retrieved 12 15, 2010, from The Mind Project: http://www.mind.ilstu.edu

Sun, H.-M., Li, S.-P., Zhu, Y.-Q., \& Hsiao, B. (2015). The effect of user's perceived presence and promotion focus on usability for interacting in virtual environments. Applied Ergonomics , 50, 126-132.

Turner, P. (2015). Presence: Is it just pretending? AI \& Society , 30 (1), 1-10.

Turner, P., Turner, S., \& Carruthers, L. (2014). It's Not Interaction, It's Make Believe. ECCE '14 Proceedings of the 2014 European Conference on Cognitive Ergonomics. New York: ACM.

van Baren, J., \& IJsselsteijn, W. (2004). Measuring Presence: A Guide to Current Measurement Approaches. Eindhoven University of Technology. Eindhoven: IST FET OMNIPRES Project.

Witmer, B. G., \& Singer, M. J. (1998). Measuring Presence in Virtual Environments: A Presence Questionnaire. Presence, 7 (3), 225-240. 